Onder redactie van:

Prof. mr. dr. B.M.E.M. Schols

Prof. mr. dr. W. Burgerhart

Prof. mr. dr. F.W.J.M. Schols

Mr. F.M.H. Hoens

Mr. G.A. Tuinstra

Mr. J.Th.M. Diks

Mr. M.J.P. Schipper

Mr. dr. N.V.C.E. Bauduin

Mr. E.C.E. Schnackers

Mr. dr. J.W.A. Rheinfeld

\section{Advotip}

Erfrecht voor de advocaat

\title{
Drie petten in één boedel: vereffenaar, schuldeiser én schuldenaar en de mogelijkheden tot schuldverrekening
}

In deze AdvoTip staan we stil bij een uitspraak van het Hof Den Haag (17 januari 2018, ECLI:NL:GHDHA:2018:131) waaruit helder blijkt dat het zaak is om bij erfrechtelijke 'conflicten' niet alleen oog te hebben voor de inhoudelijke kant van de zaak, maar ook voor de procesrechtelijke aspecten die 'eigen' zijn aan het erfrecht.

Zoals bekend, heeft een erfgenaam de keuze om een nalatenschap te aanvaarden dan wel om deze te verwerpen, artikel 4:190 lid $1 \mathrm{BW}$, eerste volzin. Aanvaarding geschiedt zuiver of beneficiair (onder het voorrecht van boedelbeschrijving), artikel 4:190 lid 1 BW tweede volzin. Beneficiaire aanvaarding heeft, onder meer, tot gevolg dat de erfgenaam in beginsel niet verplicht is om een schuld van de nalatenschap (als bedoeld in artikel 4:7 lid $1 \mathrm{BW}$ ) ten laste van zijn eigen/privévermogen te voldoen, artikel 4:184 lid 2 BW. De nalatenschapsschuldeisers kunnen hun vorderingen (slechts) verhalen op de goederen van de nalatenschap, artikel 4:184 lid $1 \mathrm{BW}$.

Voor de afwikkeling van de boedel betekent beneficiaire aanvaarding dat de nalatenschap moet worden vereffend conform de voorschriften van de derde afdeling van titel 6 Boek 4 BW, zo artikel 4:202 lid 1 aanhef BW. Op deze hoofdregel bestaan overigens een aantal uitzonderingen die eveneens zijn vermeld in artikel 4:202 BW. Is de wettelijke vereffening eenmaal van kracht, dan kunnen twee routes worden onderscheiden. De 'lichte' variant van artikel 4:221 BW en de 'zware' variant. Als wordt vereffend omdat de nalatenschap door één of meer erfgenamen beneficiair is aanvaard, dan zijn alle erfgenamen - ongeacht of zij de nalatenschap zuiver dan wel beneficiair hebben aanvaard - vereffenaar, artikel 4:195 lid $1 \mathrm{BW}$. Tenzij de kantonrechter anders bepaalt, oefenen de erfgenamen vervolgens hun bevoegdheden als vereffenaars van de beneficiair aanvaarde nalatenschap tezamen uit. Zo nodig kunnen sommige daden (daden van gewoon onderhoud, tot behoud en die geen uitstel kunnen leiden) door ieder van hen zelfstandig worden verricht, artikel 4:198 BW.

In onze zaak was erflater in januari 2017 overleden. Als erfgenamen liet hij achter zijn (tweede) echtgenote alsmede zijn twee kinderen uit een eerder huwelijk. De langstlevende en de twee kinderen hebben alle drie de nalatenschap beneficiair aanvaard. Tijdens leven had de erflater een schuldbekentenis getekend op grond waarvan de beide kinderen een vordering op hem hadden. Die vordering was ten tijde van het overlijden nog niet voldaan. 
De langstlevende echtgenote heeft de kantonrechter verzocht de vereffening op te heffen, artikel 4:209 lid 1 BW. De kantonrechter gaat hierin mee, en beveelt de opheffing. Daarvoor was mede bepalend de door de langstlevende opgestelde boedelbeschrijving. Uit het feitenrelaas kan verder worden afgeleid dat de 'geringe waarde van de baten van de nalatenschap' waarschijnlijk mede is ontstaan door het feit dat de langstlevende een beroep deed op schuldverrekening, artikel 6:127 BW:

'1 Wanneer een schuldenaar die de bevoegdheid tot verrekening heeft, aan zijn schuldeiser verklaart dat hij zijn schuld met een vordering verrekent, gaan beide verbintenissen tot hun gemeenschappelijk beloop teniet.

2 Een schuldenaar heeft de bevoegdheid tot verrekening, wanneer hij een prestatie te vorderen heeft die beantwoordt aan zijn schuld jegens dezelfde wederpartij en hij bevoegd is zowel tot betaling van de schuld als tot het afdwingen van de betaling van de vordering.

3 De bevoegdheid tot verrekening bestaat niet ten aanzien van een vordering en een schuld die in van elkaar gescheiden vermogens vallen.'

Uit het relaas kan ook worden afgeleid dat zonder die schuldverrekening door de langstlevende er een 'aanmerkelijk bedrag aan activa' is dat dan vervolgens conform de normale vereffeningsregels pondspondsgewijs had moeten worden aangewend ter voldoening van de schuldeisers, waaronder de beide kinderen.

De kinderen betwisten dat de langstlevende inderdaad een recht tot schuldverrekening toekwam en gaan in appèl tegen de beschikking van de kantonrechter. Getwist wordt over de strekking van artikel 4:217 BW:

'1 Indien iemand zowel schuldenaar als schuldeiser van de nalatenschap is, zijn de bepalingen van de Faillissementswet omtrent de bevoegdheid tot verrekening van overeenkomstige toepassing.'

En hoe deze bepaling zich verhoudt tot artikel 53 Fw:

'1 Hij die zowel schuldenaar als schuldeiser van de gefailleerde is, kan zijn schuld met zijn vordering op de gefailleerde verrekenen, indien beide zijn ontstaan vóór de faillietverklaring of voortvloeien uit handelingen, vóór de faillietverklaring met de gefailleerde verricht.'

Ter onderbouwing van hun standpunt verwijzen de kinderen naar een uitspraak van Hof Arnhem-Leeuwarden (ECLI:NL:GHARL:2015:1702). Uit de destijds door dit hof geformuleerde rechtsregels zou, zo stellen de kinderen, kunnen worden afgeleid dat niet verrekend kan worden als de schuldenaar/schuldeiser tevens ook medevereffenaar is. Kortom, in de visie van de kinderen stond de langstlevende geen beroep open op artikel 4:217 BW. De langstlevende stelt dat artikel 4:217 BW wel van toepassing is, en dat de kinderen de uitspraak van Hof Arnhem-Leeuwarden niet correct interpreteren. Volgens de langstlevende draaide die zaak om het ontstaansmoment van de vordering (voor of na faillissement) en niet om de samenloop van de hoedanigheden schuldeiser/ schuldenaar met die van vereffenaar. Dit andere 'toetsingskader' c.q. deze andere 'grondslag' zou ook blijken uit het arrest dat de Hoge Raad in cassatie wees op die hofuitspraak (ECLI:NL:HR:2016:2351) en de conclusie daarbij van de procureur-generaal (ECLI:NL:PHR:2016:840). Hoe dan ook, de langstlevende stelt:

'In de onderhavige zaak gaat het om vorderingen en schulden die vóór overlijden zijn ontstaan. Daarop zijn artikel 4:217 lid $1 \mathrm{BW}$ en $53 \mathrm{Fw}$ van toepassing. Het gaat om verrekening van een vordering van een schuldeiser terwijl de 
nalatenschap ook een vordering op deze schuldeiser heeft. ledere schuldeiser mag zijn schuld aan de boedel als "onderpand" beschouwen voor betaling van zijn vordering. Niet relevant is of de schuldenaar tevens schuldeiser dan wel tevens ook medevereffenaar is. De kantonrechter heeft dan ook juist geoordeeld.' (Curs. $\mathrm{FH})$

Over de verhouding tussen artikelen 6:127 BW en artikel 53 Fw meldt Perrick (Asser/Perrick, 4, 2017/627):

'[...] De bevoegdheid tot verrekening volgens de Faillissementswet wijkt in een aantal opzichten af van de regeling voor de verrekening in het $B W$ in het algemeen. Zie art. 53-55 Fw. Met name worden enkele vereisten die art. 6:127 lid 2 BW stelt, door de Faillissementswet terzijde gesteld. Het gaat hier om de verrekening van een vordering van een schuldeiser op de nalatenschap terwijl de nalatenschap een vordering op deze schuldeiser heeft. Zo behoeven de schulden niet opeisbaar te zijn. Verrekening kan, zo volgt uit de verwijzing in art. $53 \mathrm{Fw}$ naar art. 130 en $131 \mathrm{Fw}$ ook plaatsvinden met schulden corresponderende met vorderingen onder opschortende voorwaarde en met schulden corresponderende met vorderingen waarvan het tijdstip der opeisbaarheid onzeker is of die recht geven op periodieke uitkeringen. Art. 53 Fw geeft niet slechts een ruimere verrekening mogelijkheid dan uit art. 6:127 lid 2 BW voortvloeit. De eis die art. 53 lid $1 \mathrm{Fw}$ in afwijking van art. 6:127 lid $2 \mathrm{BW}$ stelt dat zowel de schuld als de vordering voor de faillietverklaring moeten zijn ontstaan of moeten voortvloeien uit handelingen die voor de faillietverklaring met de gefailleerde zijn verricht, houdt een beperking in van de verrekening mogelijkheden. [...]' (Curs. FH)

Interessant, het eigen schuldverrekeningsregime van de Faillissementswet is zowel ruimer als beperkter dan het reguliere artikel 6:127 BW.

Perrick vervolgt:

'[...] Daar volgens art. 6:127 lid $3 \mathrm{BW}$ de bevoegdheid tot verrekening niet bestaat ten aanzien van een vordering en een schuld, die in van elkaar gescheiden vermogens vallen, heeft de schuldeiser van de nalatenschap geen bevoegdheid tot verrekening van zijn vordering met de vordering van de erfgenaam jegens hem. Hetzelfde geldt ten aanzien van een vordering van de nalatenschap op een persoon die een schuld heeft aan een erfgenaam. Aldus ook Klaassen/Luijten \& Meijer II, Erfrecht 2008/821.

Een schuld van een erfgenaam aan de nalatenschap of een schuld van de nalatenschap aan een erfgenaam gaat niet (gedeeltelijk) door vermenging teniet. Ik zou willen aannemen dat de vordering en de schuld in van elkaar gescheiden vermogens vallen als bedoeld in art. 6:161 lid 2 onder a BW. [...]' (Curs. FH)

Over de onderhavige kwestie, de samenloop van de hoedanigheden schuldeiser/ schuldenaar en vereffenaar, zwijgt Perrick. Ook een snelle scan van enkele andere handboeken levert geen antwoord op, anders dan de opmerking van Kolkman ( $T \& B W$, art. 4:217 BW, aant. 3) dat:

'De vereffenaar kan als zodanig geen aanspraak maken op de overeenkomstige toepassing van art. 56 Fw.' (Curs. FH)

Helaas, ook het hof komt niet toe aan de beantwoording van de kwestie. De inhoudelijke behandeling komt niet aan bod omdat de spelregels van de vereffening uit het oog zijn verloren: 
'5.6 [...] Op grond van voornoemd art. 4: 195 BW zijn verzoekers 1, 2 en de verweerster dus gezamenlijk vereffenaar. Ook is komen vast te staan dat het verzoek tot opheffing van de vereffening door één van de vereffenaren, namelijk de verweerster, is ingediend bij rechtbank Den Haag team kanton. Verder staat vast dat in de procedure bij de rechtbank, team kanton, de twee andere vereffenaren, verzoekers 1 en 2, niet door de kantonrechter in de gelegenheid zijn gesteld om zich uit te laten over het verzoek gedaan door één van de vereffenaren. In hoger beroep is gebleken dat de twee andere vereffenaren het verzoek tot opheffing van de vereffening niet onderschrijven en dat zij vernietiging van de vereffeningsbeschikking verzoeken.

Gelet op het voorgaande, met name de artikelen 4:195 jo 4:209 BW, had het verzoek tot opheffing afkomstig moeten zijn van de vereffenaar, te weten de verweerster en de verzoekers 1 en 2 tezamen, of in ieder geval met instemming van de twee andere erfgenamen/vereffenaren. Nu het verzoek tot opheffing door één vereffenaar is gedaan zonder instemming van de beide andere vereffenaren, die bovendien niet als belanghebbenden zijn opgeroepen bij de mondelinge behandeling, is het verzoek tot opheffing onbevoegd gedaan. Het hof zal de bestreden beschikking vernietigen en het inleidende verzoek van de verweerster alsnog afwijzen. [...]' (Curs. FH)

Het voorgaande formele argument raakt volgens het Hof Den Haag echter ook de inhoudelijke kant van de zaak als het vervolgt:

'Dit geldt temeer nu twee van de vereffenaren de door één van de vereffenaren toegepaste verrekening op grond van artikel 4:217 BW betwisten en ter zitting bij het hof is gebleken dat de boedelbeschrijving als bedoeld in artikel 4:211 lid 2 BW alleen door één van de vereffenaren, namelijk de verweerster, is opgemaakt.' (Curs. FH)

In je eentje de boedelbeschrijving opmaken, daar 'wat' vorderingen en schulden op en aan jezelf opzetten en dan ook nog eens een beroep doen op schuldverrekening geeft in de visie van het hof geen pas. En al helemaal niet nu:

'[...] ter zitting namens verweerster [is] verklaard dat de aan het opheffingsverzoek ten grondslag gelegde boedelbeschrijving niet klopt.' (Toev. en curs. FH)

Het blijkt maar weer: het erfrecht en de boedelafwikkeling kennen eigen spelregels. Dit geldt uiteraard ook voor het afwikkelingsprocesrecht. Het is immers zonde als juridischinhoudelijke argumenten bij boedelconflicten louter op formele gronden niet getoetst zouden kunnen worden.

Neemt niet weg dat 'wij' nu wel met het onbevredigende gevoel blijven zitten dat de interessante verrekeningsvraag (betekent het samenvallen van de hoedanigheden schuldeiser/schuldenaar en vereffenaar verval van de bevoegdheid tot schuldverrekening?) in kwestie vooralsnog onbeantwoord blifft. Maar goed, wie weet krijgt deze AdvoTip nog eens een vervolg.

Tot de volgende keer!

mr. F.M.H. Hoens 


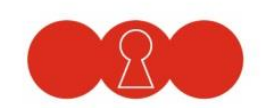

ScholsBurgerhartSchols

www.scholsburgerhartschols.nl

\section{Boomjuridisch}

Postbus 85576

2508 CG Den Haag

$\mathrm{T}(070) 3307033$

E info@boomjuridisch.nl

I www.boomjuridisch.nl

Copyright 2018 @ AdvoTip

Hoewel uiterste zorg is besteed aan de inhoud van AdvoTip - Erfrecht voor de advocaat aanvaarden de uitgever en de redactie geen aansprakelijkheid voor onvolledigheid of onjuistheid. 